\title{
Adjustment Cost Determinants and Target Capital Structure
}

\author{
Costas Lambrinoudakis* \\ University of Piraeus, Greece
}

Dynamic trade-off models of capital structure predict negative correlation between adjustment speed and adjustment costs. This paper empirically tests this prediction by bringing together elements from two strands of the literature: dynamic capital structure and security offerings literature. In contrast to existing studies, this approach employs directly measurable proxies for adjustment cost (security issuance cost) determinants. The correlation between adjustment costs and the speed of adjustment is found to be positive or zero. From a dynamic trade-off perspective, these results are puzzling as they suggest that transaction costs cannot explain the observed pattern of the capital structure adjustment process. (JEL: G30, G32)

Keywords: capital structure; target leverage; adjustment speed; security issuance costs

Article history: Received: 2 December 2014, Received in final revised form: 3 August 2015, Accepted: 27 October 2015, Available online: 10 March 2016

\section{Introduction}

The trade-off theory is the dominant theory in capital structure

\footnotetext{
* I would like to thank Panayiotis C. Andreou (Editor) and two anonymous referees, as well as Angelos Antzoulatos, Kostas Koufopoulos, Manolis Tsiritakis, Spyros Spyrou, and seminar participants at the University of Piraeus and Warwick Business School for helpful comments. I acknowledge access to the Finance Laboratory of the Department of Accounting \& Finance of the Athens University of Economics \& Business. I gratefully acknowledge financial support from Onassis Foundation. Department of Banking and Financial Management, University of Piraeus, 80 Karaoli \& Dimitriou St., 18534 Piraeus, Greece., Tel.: +30 210 4142179, e-mail: clambrin@unipi.gr
}

(Multinational Finance Journal, 2016 vol. 20, no. 1, pp. 1-39)

(C) Multinational Finance Society, a nonprofit corporation. All rights reserved. DOI: $10.17578 / 20-1-1$ 
literature. It states that the optimal leverage ratio is determined by the trade-off between the bankruptcy costs and the tax benefits arising from the use of debt. Unlike the static trade-off version, which posts that the optimal leverage ratio is determined by a single period trade-off between the tax benefits of debt and the expected costs of bankruptcy, dynamic trade-off models (e.g., Fischer, Heinkel and Zechner, 1989; Ju et al., 2005; Strebulaev, 2007) incorporate additional factors, such as optimality of financing choice in subsequent periods, transaction costs and asymmetries in taxation.

A rather common characteristic across dynamic trade-off models is that security issuance implies transaction costs. This translates into the empirical hypothesis that actual leverage ratios will revert towards an optimum/target level. In particular, firms will let their leverage ratio move away from their optimal level until the benefits from rebalancing outweigh transaction costs. ${ }^{1}$ The existence of mean-reversion in corporate leverage and the associated speed of adjustment have been at the heart of the recent empirical literature (e.g., Fama and French, 2002; Flannery and Rangan, 2006; Lemmon, Roberts and Zender, 2008; Huang and Ritter, 2009). Results are mixed, in the sense that mean-reversion is documented in all papers, but the speed of adjustment estimates differ across papers, varying from $9 \%$ to $40 \%$, depending on different econometric techniques. Put simply, it is estimated that firms close $9 \%$ to $40 \%$ of the gap between actual and desired leverage each year. The speed of adjustment is particularly important for the economic interpretation of the empirical evidence. The lower the speed of adjustment, the longer it takes for an average firm to offset deviations from the target and hence, the view that firms engage in active rebalancing of their capital structure when making financing decisions becomes more questionable.

The latest trend in the literature is the attempt to identify cross-sectional variation in adjustment costs (security issuance costs) and test whether such costs are correlated with capital structure activities. If adjustment costs do really impede firms from reaching their desired level of leverage, then higher adjustment costs should be associated with slower movements towards target leverage and vice versa. Documentation of such an empirical pattern would constitute

1. A potential view against the rebalancing argument is that the financing policy of firms is mainly determined by the attempt of managers to time the capital markets, i.e., issue debt or equity when market conditions are favorable. However, Leary and Roberts (2005) showed that leverage changes induced by market timing are quickly rebalanced away by firms. 
strong evidence in favor of active rebalancing.

Existing papers along this line of research differ mainly in the method they follow to identify cross-sectional variation in adjustment costs. Byoun (2008) explores the adjustment speed when firms issue or retire debt. He argues that when the adjustment requires debt retirement, firms with a financial surplus should adjust faster than firms with a financial deficit, because having a surplus provides a convenient time for them to adjust their capital structures with low incremental adjustment costs. Likewise, when the adjustment requires debt issuance, firms with a financial deficit should adjust faster than firms with a financial surplus. Hovakimian and $\mathrm{Li}$ (2012) explore cases of dual debt and equity issues/repurchases. The idea is that dual transactions offer greater flexibility, since they involve a combination of securities. Hence, the incremental cost of doing these transactions in a way that will move the capital structure of the firm closer to its target would be small. Faulkender et al. (2012) test the hypothesis that firms will exhibit higher adjustment speeds when the absolute deviation between actual and target leverage is lower than their absolute cash flow outcome. The idea is that these firms will engage in financial transactions anyway, so they have the opportunity to choose a combination of securities that will move them closer to their target. The results are mixed: Byoun (2008) and Faulkender et al. (2012) find evidence in favor of the negative correlation between adjustment costs and adjustment speed and Hovakimian and $\mathrm{Li}$ (2012) against.

This paper belongs and contributes to this strand of literature, namely testing of the relationship between transaction costs and adjustment speed. A different method for capturing the variation in adjustment costs is proposed. This approach brings together elements from two strands of the literature: dynamic capital structure and security offerings literature. More specifically, the determinants of security issuance costs are employed, as reported by the security offering literature (Eckbo, Masulis and Norli, 2008). These determinants are the firm's risk, the issue size and the firm's size.

The novelty of this approach is the use of measurable cross-sectional transaction cost determinants, documented in the security issuance literature, to proxy for adjustment cost variation. Furthermore, since adjustment speeds are estimated separately for cases of issuing/repurchasing debt and equity, the adjustment cost proxies can be applied in the cases where they are relevant, i.e., when firms issue debt or equity. On the contrary, existing studies (Byoun, 2008; Hovakimian and Li, 2012 and Faulkender et al., 2012) have attempted to test the relationship between adjustment costs and adjustment speed 
indirectly, i.e., by identifying circumstances that provide a convenient time for firms to adjust. Thereby, these studies -notwithstanding their significant contribution-ignore any leverage adjustments due to changes in equity (Byoun, 2008), do not disentangle security issuances from repurchases (Faulkender et al., 2012) or do not explore the cross-sectional variation in adjustment costs (Hovakimian and Li 2012).

Three different methods are applied. Firstly, the sample is split into portfolios based on each cost determinant (small vs. large, rated vs. non-rated, high-volatility vs. low-volatility), then the adjustment speeds are re-estimated for each portfolio and the results across portfolios are compared. Secondly, an empirical model developed by Faulkender et al. (2012) is employed for the estimation of the incremental effect of cost determinants on adjustment speed. Finally, an empirical model developed by Altinkiliç and Hansen (2000) is used for the estimation of security issuance costs. Then, portfolios based on these estimates (high cost vs. low cost) are formed and the speeds of adjustment across the portfolios are compared.

Although evidence in favor of mean-reversion is detected, there is no supporting evidence for the predicted negative relationship between adjustment speed and adjustment costs. In particular, firms are found to make the financial choices that will move them closer to their targets under all four financing states, i.e., when issuing/repurchasing debt and when issuing/repurchasing equity. However, the estimates imply that firms adjust faster when they issue equity, i.e., when firms are over-levered and have a financial deficit, rather than debt, i.e., when firms are under-levered and have a financial deficit. This result contradicts the dynamic trade-off theory, as equity is a more costly security to issue.

As far as the relevance of transaction costs is concerned, the results are also not consistent with dynamic trade-off theory. In terms of book leverage, when firms issue debt, the adjustment speed is not affected by the variation of adjustment costs. The difference in adjustment speed between large and small, rated and non-rated, and high and low volatility firms is statistically not different from zero. In terms of market leverage, the estimates suggest the small, non-rated and high volatility firms adjust faster than large, rated and low volatility firms, respectively. Both results contradict dynamic trade-off theory, which predicts that adjustment speed is negatively correlated with adjustment costs. The results for equity issues point to the same direction across all three cost determinants and across both leverage specifications. When issuing equity, small firms adjust faster than large firms, firms without a bond rating adjust faster than firms whose debt is rated and high 
volatility firms adjust faster than low-volatility firms. These estimates indicate that the adjustment speed rises as adjustment costs increase, an observation that is at odds with dynamic trade-off theory.

The second test concerning the incremental effect of costs on adjustment speed delivers similar results. In cases of equity issuance, the adjustment speed of firms decreases with size, and increases with stock return volatility, while the existence of a debt rating is negatively correlated with adjustment speed. Likewise, in cases of debt issuance, no negative relationship between adjustment speed and adjustment costs is detected when stock return volatility or the existence of a bond rating are considered. The incremental effect of firm size is an exception, in the sense that it is found positive and significant, implying a negative relation between adjustment costs and adjustment speed. However, this is a rather weak result, because it is only marginally significant at the $10 \%$ level and economically trivial. ${ }^{2}$

The results from the third test corroborate previous findings. Based on Altinkiliç and Hansen (2000) empirical model, when issuing equity or debt, firms facing lower security issuance costs are not found to adjust faster than firms facing higher security issuance costs.

These results are robust across many alternative specifications of the basic model. In particular, these results remain qualitatively unchanged under different econometric techniques, different ways of estimating target leverage and different time horizons over which leverage changes take place. Furthermore, several robustness checks imply that results are not driven by mechanical mean reversion or the endogeneity of the financial deficit of the firms.

In summary, a wide array of tests incorporating directly measurable proxies for adjustment costs do not detect any evidence of a negative correlation between adjustment speed and adjustment costs. Firms adjust faster when they issue equity rather than debt, even though equity is a more costly security to issue. Moreover, large, rated and low-volatility firms do not adjust faster than small, unrated and high-volatility firms, respectively, even though the former face lower adjustment costs than the latter. These results indicate that either adjustment costs are irrelevant to the adjustment process or that the partial adjustment models currently used in the literature are incapable of determining whether firms follow the financing policy predicted by the dynamic trade-off theory. The latter conjecture seems more

2. The estimated increase in adjustment speed is $2.2 \%$ whereas all other statistically significant changes range from $8.5 \%$ to $20.3 \%$. 
plausible, given that additional financing policy determinants predicted by the dynamic trade-off theory, such as expectations for future financing needs, are not included in empirical models currently used in the literature.

The paper is organized as follows. Section II illustrates the target adjustment model and the transaction cost determinant tests employed, Section III presents the dataset that is used, Section IV presents and discusses the results, Section V illustrates the robustness checks and Section VI contains the conclusions.

\section{Methodology}

\section{A. Baseline estimation of the speed of adjustment}

The following standard partial-adjustment model is employed for testing for leverage mean-reversion:

$$
\frac{D_{i, t}}{A_{i, t}}-\frac{D_{i, t-1}}{A_{i, t-1}}=\alpha+\lambda D E V_{i, t}+\varepsilon_{i, t}
$$

where

$$
D E V_{i, t}=\left[\frac{D}{A}\right]_{i, t}^{*}-\frac{D_{i, t-1}}{A_{i, t-1}}
$$

$D_{i, t}$ is firm's $i$ outstanding debt at time $t, A_{i, t}$ is firm's $i$ total assets at time $t$ and $D E V_{i, t}$ is the deviation of firm's $i$ target leverage for time $t$ from the actual leverage at time $t-1$. The coefficient of interest, which expresses the speed of adjustment, is $\lambda$. A positive and significant $\lambda$ implies that leverage is mean-reverting. For example, an estimated value of 0.65 implies that on average firms close $65 \%$ of the gap between current and desired leverage per year. The closer it is to 1 , the fuller the adjustment is. The target leverage is estimated by regressing observed leverage ratios on firm characteristics that are assumed to affect optimal leverage:

$$
\left[\frac{D}{A}\right]_{i, t}=\beta X_{i, t-1}+\varepsilon_{i, t}
$$

$X_{i, t-1}$ is the set of firm characteristics for firm $i$ at time $t-1$, which are 
described below. The fitted value from equation (2) is then substituted to the adjustment equation (1):

$$
\left[\frac{D}{A}\right]_{i, t}^{*}=\hat{\beta} X_{i, t-1}
$$

Equation (3) is estimated via the approach of Hovakimian and $\mathrm{Li}$ (2011). According to this approach, $\hat{\beta}$ is estimated separately for each year by rolling historical firm fixed-effects panel regressions. More specifically, for any year $t, \hat{\beta}_{t}$ is obtained by regressing leverage ratios observed in years 2 through $t$ on firm characteristics observed in years 1 to $t-1$. Then, the estimated coefficients are used to generate proxies for target at time $t+1$, i.e., out of sample. In that way, the potential look-ahead bias when estimating equation (3) is eliminated.

Equation (2) is estimated via OLS with firm fixed effects. Standard errors are robust to heteroskedasticity and to residual dependence within firms (White standard error clustered by firm). ${ }^{3}$ Partial-adjustment models (equation 2 and equation 5) are estimated via the Fama-MacBeth (Fama and MacBeth, 1973) approach. ${ }^{4}$ This approach involves estimating the empirical model separately for each year in the sample (cross-sectionally). Each coefficient is estimated as the mean of the respective annual coefficients. Each coefficient's t-statistic is estimated as the mean of the respective annual coefficients divided by the standard error of the estimated coefficient.

The set of firm characteristics, used to estimate target leverage, consists of factors that have been documented in previous empirical research (e.g., Flannery and Rangan, 2006; Faulkender et al., 2012) as being correlated with the leverage ratios of firms. According to the findings of these papers, these factors affect leverage in the way predicted by the trade-off theory. Size is expected to have a positive

3. For robustness, target leverage is also estimated with the one-step model. It is estimated via Blundell and Bond's (1998) system GMM, as suggested by Flannery and Hankins (2013), and the results do not change.

4. The majority of all prior studies that utilize the two-step version of the partial adjustment model, have used either Fama-MacBeth (Fama and French, 2002; Hovakimian and Li, 2010; Hovakimian and Li, 2011) or OLS with bootstrapped standard errors to account for the generated regressor (Kayhan and Titman, 2007; Faulkender et al, 2012). For robustness, I also estimate the model with OLS with bootstrapped standard errors and results do not change. 
impact on leverage, as large firms are thought of as more diversified, with less volatile earnings and therefore as having lower default risk. Profitability and leverage should be negatively related, as firms passively accumulate profits/losses and let their leverage mechanically drift most of the time until an upper or lower boundary is reached. Firms with high depreciation expenses should have lower leverage, since they have less need for deductible interest expenses. Tangibility of assets should be associated with higher leverage, because tangible assets are easier to collateralize and suffer a smaller loss in their value than intangibles in the event of bankruptcy. Likewise, firms with high R\&D expenses and/or high market-to-book ratios have usually more intangible assets and therefore are expected to have lower leverage. Finally, earlier studies (e.g., Bradley, Jarrell and Kim, 1984) have documented significant positive industry effects on leverage. This effects are interpreted as reflecting otherwise omitted industry-specific factors.

\section{B. Adjustment speed by deviation from target leverage and cash flow outcome}

According to dynamic trade-off theory of capital structure, firms have optimal leverage ratios, which are determined from the trade-off between the tax benefits and the expected distress costs of debt. Furthermore, most dynamic trade-off models assume costly adjustment, i.e., costly recapitalization (e.g., Fischer, Heinkel and Zechner, 1989; Strebulaev, 2007). The implication stemming from this assumption is that a firm's actual leverage ratio will not be always at the optimal level. Firms will let their leverage ratio move away from their optimal/target level until the benefits from rebalancing outweigh transaction costs. At this point firms will rebalance their capital structure in such a way that their leverage ratio is brought back at the target level.

The aforementioned implication translates to the empirical hypothesis that the speed of adjustment towards target leverage, i.e., the

fraction of the gap between actual and desired leverage that firms close each year on average, will be negatively correlated to adjustment costs. The reason is the following. As long as leverage stays within the rebalancing boundaries, firms are indifferent to the deviation between actual and target leverage and therefore take no rebalancing action. Consequently, the wider this "indifference" range around target 


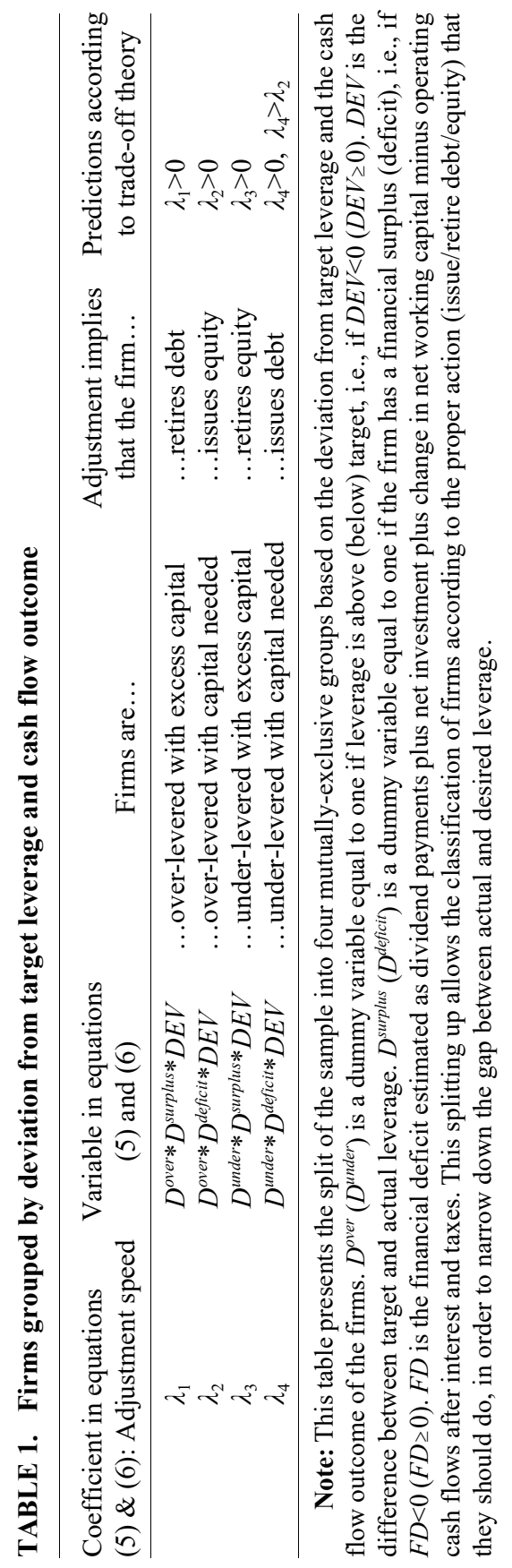


leverage, the more infrequent the rebalancing will be and hence the lower the speed of adjustment, as defined above. Given that the distance of the rebalancing boundaries from the target is an increasing function of transaction costs, the speed of adjustment should be negatively related to the adjustment costs.

The empirical literature has recently started to test this implication by trying to identify cross-sectional variation in adjustment costs and test whether this variation is correlated with adjustment speed. Instead of estimating a uniform speed of adjustment for the whole sample, these studies split the sample of firms into different groups according to the cross-sectional variation of adjustment costs and allow for heterogeneity in the speed of adjustment across the groups (Byoun, 2008; Warr et al., 2012). The division of the sample is done with dummy variables, which are incorporated into the partial adjustment model and indicate whether a firm falls into a particular group in a particular year. The testable hypothesis is that groups of low-cost firms will adjust faster than groups of high-cost firms.

Along this line of research, the sample is split into four mutually-exclusive groups depending on whether firms in a particular year are above or below their leverage targets and whether they face a financial deficit or surplus. Essentially, the characteristic that distinguishes the four groups is the financial action through which adjustment to target can be achieved. As illustrated in table 1, adjustment to target for overlevered (underlevered) firms with financial surplus calls for repurchasing debt (equity), while adjustment to target for overlevered (underlevered) firms with financial deficit calls for issuing equity (debt). The goal is to identify the firm-years, where adjustment can be achieved through issuing debt or equity. This is very important to subsequent analysis, because it enables the application of the adjustment cost proxies, i.e. security issuance cost determinants, only in the cases where they are relevant, that is when firms issue debt or equity.

The first step is the estimation of the annual cash flow outcomes of firms. The employed measure is derived from the cash flow identity $O C F_{i, t}-I_{i, t}-\Delta W_{i, t}=-\Delta D_{i, t}+D I V_{i, t}-\Delta E_{i, t}$ :

$$
F D=D I V_{i, t}+I_{i, t}+\Delta W_{i, t}-O C F_{i, t}
$$


where $D I V$ is dividend payments, $I$ is net investment, $\Delta W$ is change in net working capital, $O C F$ is operating cash flows after interest and taxes, $\Delta D$ is change in net debt issues and $\Delta E$ is change in net equity issues. ${ }^{5} F D$ stands for financial deficit. Positive values for $F D$ imply financial deficits and negative values imply financial surpluses.

Next, the following model is employed, capturing the potential asymmetry in the speed of adjustment across different groups:

$$
\begin{aligned}
\frac{D_{i, t}}{A_{i, t}}-\frac{D_{i, t-1}}{A_{i, t-1}}= & \alpha_{1} D_{i, t}^{\text {over }} D_{i, t}^{\text {surplus }}+\alpha_{2} D_{i, t}^{\text {over }} D_{i, t}^{\text {deficit }} \\
& +\alpha_{3} D_{i, t}^{\text {under }} D_{i, t}^{\text {surplus }}+\alpha_{4} D_{i, t}^{\text {under }} D_{i, t}^{\text {deficit }} \\
& +\lambda_{1} D_{i, t}^{\text {over }} D_{i, t}^{\text {surplus }} D E V_{i, t}+\lambda_{2} D_{i, t}^{\text {over }} D_{i, t}^{\text {deficit }} D E V_{i, t} \\
& +\lambda_{3} D_{i, t}^{\text {under }} D_{i, t}^{\text {surplus }} D E V_{i, t}+\lambda_{4} D_{i, t}^{\text {under }} D_{i, t}^{\text {deficit }} D E V_{i, t}+\varepsilon_{i, t}
\end{aligned}
$$

$D^{\text {over }}\left(D^{\text {under }}\right)$ is a dummy variable equal to one if leverage is above (below) target, i.e., if $D E V<0(D E V \geq 0)$. $D^{\text {surplus }}\left(D^{\text {deficit }}\right)$ is a dummy variable equal to one if the firm has a financial surplus (deficit), i.e., if $F D<0(F D \geq 0)$. Essentially, this specification divides the sample into four groups, depending on whether a firm is under- or over-levered and whether it faces a financial deficit or surplus. This distinction, as illustrated in table 1, allows the identification of the proper action that a firm should take in each case (issue/retire debt/equity) in order to narrow down the gap between actual and desired leverage. Specifically, the adjustment towards the target for an over-levered (under-levered) firm with financial surplus requires retiring debt (equity). This would manifest itself in a positive $\lambda_{1}\left(\lambda_{3}\right)$ in equation (5). On the contrary, if an over-levered (under-levered) firm with financial surplus retired equity (debt) instead of debt (equity) with its excess cash flow, this choice would then result in a further widening of the gap between actual and desired leverage. This would imply a negative $\lambda_{1}\left(\lambda_{3}\right)$. Likewise, the adjustment towards the target for an over-levered (under-levered) firm with financial deficit requires issuing equity (debt). This would manifest

5. See appendix A for the exact definition of the variables used. 
itself in a positive $\lambda_{2}\left(\lambda_{4}\right)$ in equation (5). Regarding the constant terms, they are included in order to capture changes in leverage that are not associated with target-adjustment motives. For example, a firm will still have to accommodate its financing gap (whether positive or negative) even when its leverage ratio is within the "indifference" range around target leverage.

The dynamic trade-off theory predicts that firms actively adjust their leverage ratio towards their target. So, if leverage is indeed mean-reverting, then $\lambda_{1}, \lambda_{2}, \lambda_{3}$ and $\lambda_{4}$ should be positive and significant. This would be consistent with the predictions of trade-off theory. In addition, if dynamic trade-off theory holds true, then $\lambda_{4}$ should be greater than $\lambda_{2}$. The rationale is that issuing debt is cheaper than issuing equity, thus the adjustment through debt issues should be faster than the adjustment through equity issues. ${ }^{6}$ A paired t-test is used to statistically test the difference between $\lambda_{4}$ and $\lambda_{2}{ }^{7}$

The empirical model (equation 5) is based on a model used by Byoun (2008) that divides firm-years into mutually-exclusive groups based on deviation from target leverage and cash flow outcome. Although the two models look similar at first glance, they exhibit a significant difference. In particular, the dependent variable in Byoun's specification is $D_{i, t} / A_{i, t}-D_{i, t-1} / A_{i, t}$, while in my specification it is $D_{i, t} / A_{i, t}-D_{i, t-1} / A_{i, t-1}$. Additionally, the independent variable in Byoun's model is $D E V_{i, t}=[D / A]_{i, t}^{*}-D_{i, t-1} / A_{i, t}$, while in my specification it is $D E V_{i, t}=[D / A]_{i, t}^{*}-D_{i, t-1} / A_{i, t-1}$. That is, my model tests if leverage exhibits target-adjustment behavior, regardless of whether the adjustment, i.e., the change in leverage, comes from a change in debt or in equity. In contrast, Byoun's model tests if leverage exhibits target-adjustment behavior, taking into account only the changes in leverage that are due to a change in debt and ignoring any leverage changes that come from equity changes. This difference changes dramatically the interpretation of the coefficients. In Byoun's specification, the coefficients $\lambda_{1}$ and $\lambda_{2}\left(\beta_{3}\right.$ and $\beta_{4}$ according to his notation) measure the adjustment speed through debt retirement when

6. Altinkiliç and Hansen (2000) and Kim, Palia and Saunders (2008) provide evidence that the issuance costs of debt are on average five times cheaper than the issuance costs of equity.

7. Model (5) is estimated with the Fama-MacBeth (Fama and MacBeth, 1973) approach. Therefore, the paired t-test is the appropriate method to test for the difference between the two coefficients. 
firms have a financial surplus or deficit, respectively. He finds, as expected, that the former adjust faster than the latter. Likewise, the coefficients $\lambda_{3}$ and $\lambda_{4}\left(\beta_{5}\right.$ and $\beta_{6}$ according to his notation) measure the adjustment speed through debt issuance when firms have a financial surplus or deficit, respectively. He finds, as expected, that the latter adjust faster than the former.

The preceding analysis shows clearly that the specification of Byoun differs significantly from mine and, most importantly, would be inappropriate for this study. The reason is that this study focuses on security issuance costs and thus the speed of adjustment when debt or equity is issued has to be estimated. The specification of Byoun allows only for the former, whereas my specification allows for both.

\section{Adjustment speed and adjustment cost determinants}

Next, the relation between variation in adjustment speeds and differential adjustment costs is investigated, i.e., if slower (faster) adjustment is the result of higher (lower) costs. Therefore, the variation in adjustment speeds is examined with respect to the determinants of security issuance costs. After having extensively researched this topic, the security offerings literature reports that the most significant factors determining security issuance costs are (a) firm size, (b) firm risk and (c) issue size ${ }^{8}$ Firm size is negatively related to costs, is usually proxied by total assets or net sales and is interpreted as capturing information asymmetries and asset diversification. Firm risk is positively related to costs and is usually proxied by the volatility of the firm's stock returns or the existence of a bond rating. Firms whose debt is rated and/or whose stock is less volatile are considered as less risky. Issue size is usually proxied by the amount of issue proceeds, while its relationship with costs is u-shaped. This relationship is interpreted as implying that security issuance costs entail both fixed and variable parts.

Three methods are employed to examine the variation in adjustment speeds with respect to the determinants of security issuance costs.

Firstly, the sample is split into groups based on firm size, proxied by total assets, and firm risk, proxied by the volatility of the firm's stock returns or alternatively by the existence of a bond rating or not. The last determinant, issue size, is not used in this part of the analysis, because it does not have a monotonic relationship with costs. When the variable

8. See Eckbo, Masulis and Norli (2008) for a thorough literature review. 
used to divide up the sample is continuous, the median is used as the cut-off point. Hence, three pairs of groups are constructed, i.e., small vs. large, rated vs. non-rated and low volatility vs. high volatility. Then, adjustment speeds are re-estimated for each portfolio. If transaction costs do matter, then adjustment speeds when equity or debt is issued (coefficients $\lambda_{2}$ and $\lambda_{4}$ respectively) should rise with decreasing costs and vice versa. For example, the estimated $\lambda_{2}$ for large firms is expected to be higher than the estimated $\lambda_{2}$ of the small firms. Likewise, the estimated $\lambda_{4}$ for large firms is expected to be higher than the estimated $\lambda_{4}$ of the small firms. For every partition, the difference between the coefficients of different groups is statistically tested with a paired t-test.

Secondly, an alternative specification is employed to examine the association between adjustment costs and adjustment speed. The target adjustment model is extended to capture the incremental effect of cost determinants on adjustment speed in a way similar to the extension done by Faulkender et al. (2012):

$$
\begin{aligned}
\frac{D_{i, t}}{A_{i, t}}-\frac{D_{i, t-1}}{A_{i, t-1}}= & \alpha_{1} D_{i, t}^{\text {over }} D_{i, t}^{\text {surplus }}+\alpha_{2} D_{i, t}^{\text {over }} D_{i, t}^{\text {deficit }} \\
& +\alpha_{3} D_{i, t}^{\text {under }} D_{i, t}^{\text {surplus }}+\alpha_{4} D_{i, t}^{\text {under }} D_{i, t}^{\text {deficit }} \\
& +\left(\lambda_{1}+\gamma_{1} \mathrm{Z}_{i, t}\right) D_{i, t}^{\text {over }} D_{i, t}^{\text {surplus }} D E V_{i, t} \\
& +\left(\lambda_{2}+\gamma_{2} \mathrm{Z}_{i, t}\right) D_{i, t}^{\text {over }} D_{i, t}^{\text {deficit }} D E V_{i, t} \\
& +\left(\lambda_{3}+\gamma_{3} Z_{i, t}\right) D_{i, t}^{\text {under }} D_{i, t}^{\text {surplus }} D E V_{i, t} \\
& +\left(\lambda_{4}+\gamma_{4} Z_{i, t}\right) D_{i, t}^{\text {under }} D_{i, t}^{\text {deficit }} D E V_{i, t}+\varepsilon_{i, t}
\end{aligned}
$$

Equation (6) is estimated three times, one for each cost proxy $(Z)$, namely total assets, stock return volatility and the existence of a bond rating. The first two, being continuous variables, are normalized to have a mean of zero and a standard deviation of one to ease economic interpretation. The existence of a bond rating is captured by a dummy variable equal to one when the firm has a bond rating and zero otherwise.

The interpretation of the coefficients are as follows. The coefficients $\lambda$ capture the adjustment speed of the "base" firm. Suppose that $Z$ is 
normalized total assets (stock return volatility). The coefficients $\lambda_{1}, \lambda_{2}$, $\lambda_{3}$ and $\lambda_{4}$ measure the adjustment speed of the firm whose size (stock return volatility) is at the sample mean, when target adjustment requires retiring debt, issuing equity, retiring equity and issuing debt, respectively. The coefficients $\gamma_{\mathrm{i}}$ measure the proportional incremental effect of size (stock return volatility) on the respective adjustment speed coefficient. For example, an estimated $\gamma_{2}=0.2$ would imply that, when target adjustment requires issuing equity, a firm that is one standard deviation above the mean size (stock return volatility) adjusts to the target by $20 \%$ faster than an average size (stock return volatility) firm. Suppose now that $Z$ is the bond rating dummy. In that case the "base firm" corresponds to the unrated firms. The coefficients $\lambda_{1}, \lambda_{2}, \lambda_{3}$ and $\lambda_{4}$ measure the adjustment speed of unrated firms, while coefficients $\gamma_{i}$ measure the proportional incremental effect of the existence of a bond rating on the respective adjustment speed coefficient. For example, an estimated $\gamma_{2}=0.2$ would imply that, when issuing equity, a rated firm adjusts to the target by $20 \%$ faster than an unrated firm.

Given that the trade-off theory predicts that firms actively pursue their leverage targets, $\lambda_{1}, \lambda_{2}, \lambda_{3}$ and $\lambda_{4}$ are expected to be positive. However, the coefficient of main interest in this model is $\gamma$. Given that lower security issuance costs imply higher adjustment speeds, $\gamma_{2}$ and $\gamma_{4}$ are expected to be positive when size and bond rating are considered, and negative when stock return volatility is considered.

Finally, two empirical models developed by Altinkiliç and Hansen (2000) are employed to estimate equity and debt issuance costs: ${ }^{9}$

$$
\begin{aligned}
\text { Equity issuance cost }= & 4.04+25.65 *(1 / \text { proceeds }) \\
& +2.64 *(\text { proceeds } / \text { market cap }) \\
\text { Debt issuance cost }= & 0.50+25.17 *(1 / \text { proceeds }) \\
& +4.63 *(\text { proceeds } / \text { market cap })
\end{aligned}
$$

Proceeds are the net change in equity or debt in each fiscal year, and market cap is the market capitalization of the firm at the end of the relevant fiscal year. The estimated cost for each year is assumed to apply for all issuances that took place in that particular year. ${ }^{10}$ Then,

9. p. 201, table 2, Model 3 and p.211, table 5, Model 3 respectively

10. Leary and Roberts (2005) make a similar assumption when they use an analogous model by Altinkiliç and Hansen (2000) 
groups are formed on the basis of the estimated costs (high cost vs. low cost) and finally, the adjustment speeds across the groups are compared.

\section{Data}

Accounting data is drawn from Compustat, has an annual frequency and covers the period 1971-2010. Cash flow statement data, which is necessary for the analysis, is available from 1971 onwards. Stock market data is drawn from CRSP-Compustat merged database. Following the approach taken in previous research, financial firms (SIC 6000-6999) and utilities (SIC 4900-4999) are excluded. Firm-years with firms that have nonpositive total assets, book or market value of equity or net sales are excluded, as these variables are used to standardize other variables and thus cannot be zero or negative. Firm-years with firms, for which the accounting cash flow identity $O C F_{i, t}-I_{i, t}-\Delta W_{i, t}=-\Delta D_{i, t}+$ $D I V_{i, t}-\Delta E_{i, t}$ doesn't hold, are also excluded. Several cash flow statement accounts, which are used to calculate these six variables, are not reported or combined with other accounts in the cash flow statement in Compustat. The reason is that many firms do not report such data at all and Compustat classifies that data as missing. In order to avoid losing many observations, I replace all missing and combined values in these accounts with zero and keep the firm-years, for which the cash flow identity is not violated. Firms with a cash flow statement whose format code is either 4, 5 or 6 ( 5 is for Canadian firms and 4 and 6 are not specified by Compustat) and of course firm-years with missing observations are excluded.

Active leverage changes are separated from passive and the latter are excluded. Passive leverage changes are mechanical accounting changes, such as transferring the annual profit or loss to the corresponding equity account. Following the approach taken by previous researchers (e.g., Hovakimian, Opler and Titman, 2001; Leary and Roberts, 2005), I define a debt issuance or repurchase as any annual net change in the book value of debt above $5 \%$ of the book value of assets in the previous fiscal year. Likewise, a firm is defined as having issued or repurchased equity when the net value of equity issued or repurchased within a fiscal year is at least $5 \%$ of the book value of assets in the previous fiscal year. Equity repurchases use a $1.25 \%$ cut-off point, as there are numerous smaller-sized repurchase programs (Leary and Roberts, 2005).

The sample resulting from application of all the aforementioned 
TABLE 2. Summary Statistics

\begin{tabular}{|c|c|c|c|c|c|}
\hline Variable & Mean & Std. Dev. & Min & Max & Obs. \\
\hline$T D / B A$ & 0.2562 & 0.1864 & 0.0000 & 0.7418 & 72,634 \\
\hline$T D / M A$ & 0.2141 & 0.1839 & 0.0000 & 0.7197 & 72,634 \\
\hline$D \_O V E R(T D / B A)$ & 0.4384 & 0.4962 & 0.0000 & 1.0000 & 72,634 \\
\hline$D_{-} U N D E R(T D / B A)$ & 0.5616 & 0.4962 & 0.0000 & 1.0000 & 72,634 \\
\hline D_OVER (TD/MA) & 0.4043 & 0.4908 & 0.0000 & 1.0000 & 72,634 \\
\hline$D_{-}^{-} U N D E R(T D / M A)$ & 0.5957 & 0.4908 & 0.0000 & 1.0000 & 72,634 \\
\hline D_DEFICIT & 0.6058 & 0.4887 & 0.0000 & 1.0000 & 72,634 \\
\hline D_SURPLUS & 0.3942 & 0.4887 & 0.0000 & 1.0000 & 72,634 \\
\hline$\overline{M E D}(T D / B A)$ & 0.1992 & 0.0938 & 0.0000 & 0.5430 & 72,634 \\
\hline$M E D(T D / M A)$ & 0.1567 & 0.0980 & 0.0000 & 0.6366 & 72,634 \\
\hline EBITDA & 0.0656 & 0.2181 & -1.0962 & 0.4036 & 72,634 \\
\hline$M B$ & 1.8379 & 1.6819 & 0.5006 & 12.3104 & 72,634 \\
\hline $\operatorname{Ln} A$ & 4.4234 & 2.1289 & -3.5512 & 12.8777 & 72,634 \\
\hline$D E P$ & 0.0498 & 0.0374 & 0.0000 & 0.2218 & 72,634 \\
\hline$F A$ & 0.3215 & 0.2386 & 0.0000 & 0.9171 & 72,634 \\
\hline$R \& D$ & 0.2129 & 1.4246 & 0.0000 & 17.2897 & 72,634 \\
\hline$R \& D$ dummy & 0.4583 & 0.4983 & 0.0000 & 1.0000 & 72,634 \\
\hline
\end{tabular}

Note: This table reports summary statistics for the employed variables. $T D$ is total debt and $B A(M A)$ is book (market) value of assets. $D^{\text {over }}\left(D^{\text {under }}\right)$ is a dummy variable equal to one if leverage is above (below) target, i.e. if $D E V<0(D E V \geq 0)$. $D E V$ is the difference between target and actual leverage. $D^{\text {surplus }}\left(D^{\text {deficit }}\right)$ is a dummy variable equal to one if the firm has a financial surplus (deficit), i.e. if $F D<0(F D \geq 0) . F D$ is the financial deficit estimated as dividend payments plus net investment plus change in net working capital minus operating cash flows after interest and taxes. $M E D$ is the median leverage of the industry (based on Fama French 49 industry groups) that the firm belongs to. EBITDA is earnings before interest, taxes, depreciation and amortization divided by book assets. $M B$ is the sum of book liabilities plus market value of equity divided by book assets. $L n A$ is the natural $\log$ of book assets expressed in 1983 US dollars. $D E P$ is depreciation and amortization divided by book assets. $F A$ is fixed assets divided by book assets. $R \& D$ is research and development expense divided by net sales. Missing values of $R \& D$ are set to zero. $R \& D$ dummy is a dummy variable equal to one if the firm doesn't report $R \& D$ expense and zero otherwise.

restrictions consists of 72,634 firm-year observations. Table 2 defines variables and presents summary statistics. This is of course the initial sample. Depending on the required data for different types of analysis in the course of the study, the number of usable firm-year observations will vary accordingly. Variables are measured in constant 1983 dollars using the US CPI as a deflator. I winsorize all final variables at the $1^{\text {st }}$ and the $99^{\text {th }}$ percentile to avoid the effect of outliers and misreported data. ${ }^{11}$

11. Dividends and R\&D expenses are winsorized at the $99^{\text {th }}$ percentile only, as many 


\section{Results}

\section{A. Baseline results}

Leverage is calculated as financial debt, i.e., interest bearing liabilities over total assets. ${ }^{12}$ Both leverage specifications are used, that is book leverage and market leverage. Book leverage is total debt over book value of assets, while market leverage is total debt over market value of assets.

The results from regressing leverage on firm characteristics that affect target leverage (equation 2) are consistent with previous literature (e.g., Flannery and Rangan, 2006; Faulkender et al., 2012). In particular, profitability, growth, depreciation expenses and $R \& D$ expenses have a negative effect on leverage, while the firm's industry median leverage, firm size and tangibility of assets have a positive effect on leverage. The results hold under both leverage specifications, i.e., book and market leverage.

First, the adjustment speed is estimated for the whole sample, that is without splitting the sample into groups. The partial-adjustment model (equation 1) is estimated for an extended sample, i.e., without eliminating firm-year observations with passive leverage changes, so that estimates can be compared with those of the existing literature. I find an adjustment speed estimate of $18.9 \%$ per year for book leverage and $21.6 \%$ per year for market leverage. This result closely resembles previous reported adjustment speeds, estimated from rolling historical panel specifications (Hovakimian and Li, 2011; Hovakimian and $\mathrm{Li}$, 2012). Alternative specifications such as GMM and OLS -without using rolling historical regressions- are also employed and the results are in line with existing literature.

Next, the analysis is restricted to the main sample, which consists only of firm-year observations with active leverage changes. The adjustment speed is significantly increased, reaching $31.1 \%$ per year for book leverage and 33\% per year for market leverage. This increase indicates that the screening technique does a good job in capturing active adjustment.

firms do not pay dividends or don't make R\&D expenses.

12. Detailed results are not presented for brevity in this subsection, but are available upon request. 
TABLE 3. Adjustment speeds by deviation from target leverage and cash flow outcome

\begin{tabular}{|c|c|c|c|c|}
\hline $\begin{array}{l}\text { Target adjustment } \\
\text { implies that the } \\
\text { firm... }\end{array}$ & & & Book leverage & Market leverage \\
\hline & $D^{\text {over } *} D^{\text {surplus }}$ & $\alpha_{1}$ & $\begin{array}{l}-0.0417^{* * *} \\
(-15.10)\end{array}$ & $\begin{array}{l}-0.0389 \text { *** } \\
(-8.33)\end{array}$ \\
\hline & $D^{\text {over } *} D^{\text {deficit }}$ & $\alpha_{2}$ & $\begin{array}{l}0.0463^{* * *} \\
(13.50)\end{array}$ & $\begin{array}{l}0.0410^{* * * *} \\
(8.02)\end{array}$ \\
\hline & $D^{\text {under } *} D^{\text {surplus }}$ & $\alpha_{3}$ & $\begin{array}{l}-0.0344^{* * *} \\
(-17.36)\end{array}$ & $\begin{array}{l}-0.0289^{* * *} \\
(-7.74)\end{array}$ \\
\hline & $D^{\text {under } *} D^{\text {deficit }}$ & $\alpha_{4}$ & $\begin{array}{l}0.0443^{* * *} \\
(15.40)\end{array}$ & $\begin{array}{l}0.0385^{* * * *} \\
(7.80)\end{array}$ \\
\hline ...retires debt & $D^{\text {over } *} D^{\text {surplus } *} D E V$ & $\lambda_{1}$ & $\begin{array}{l}0.2408^{* * *} \\
(10.69)\end{array}$ & $\begin{array}{l}0.3352^{* * * *} \\
(13.25)\end{array}$ \\
\hline ...issues equity & $D^{\text {over } *} D^{\text {deficit } *} D E V$ & $\lambda_{2}$ & $\begin{array}{l}0.3841 \text { *** } \\
(21.60)\end{array}$ & $\begin{array}{l}0.3747^{* * * *} \\
(15.83)\end{array}$ \\
\hline ...retires equity & $D^{\text {under } *} D^{\text {surplus } *} D E V$ & $\lambda_{3}$ & $\begin{array}{l}0.1294^{* * *} \\
(5.00)\end{array}$ & $\begin{array}{l}0.1610^{* * *} \\
(5.96)\end{array}$ \\
\hline \multirow[t]{4}{*}{...issues debt } & $D^{\text {under } *} D^{\text {deficit } *} D E V$ & $\lambda_{4}$ & $\begin{array}{l}0.2237^{* * * *} \\
(14.19)\end{array}$ & $\begin{array}{l}0.1897 * * * \\
(12.41)\end{array}$ \\
\hline & Adjusted $\mathrm{R}^{2}$ & & 0.1720 & 0.182 \\
\hline & Observations & & 72,634 & 72,634 \\
\hline & $\begin{array}{l}\text { p-value of equality of } \\
\lambda_{2} \text { and } \lambda_{4}\end{array}$ & & {$[0.000]$} & {$[0.000]$} \\
\hline
\end{tabular}

Note: This table presents results from estimating equation (5) via Fama-MacBeth regressions. The dependent variable is leverage in first differences. The sample is split into four mutually-exclusive groups based on the deviation from target leverage and the cash flow outcome of the firms. $D^{\text {over }}\left(D^{\text {under }}\right)$ is a dummy variable equal to one if leverage is above (below) target, i.e., if $D E V<0(D E V \geq 0) . D E V$ is the difference between target and actual leverage. $D^{\text {surplus }}\left(D^{\text {deficit }}\right)$ is a dummy variable equal to one if the firm has a financial surplus (deficit), i.e., if $F D<0(F D \geq 0)$. $F D$ is the financial deficit estimated as dividend payments plus net investment plus change in net working capital minus operating cash flows after interest and taxes. Numbers in parentheses are t-statistics. Numbers in brackets are p-values. The $\mathrm{p}$-values of equality of $\lambda_{2}$ and $\lambda_{4}$ are for the t-statistics from paired t-tests of the null hypothesis that the difference between the two coefficients is zero. $* * *, * *$ and $*$ indicate $1 \%$, $5 \%$ and $10 \%$ statistical significance levels, respectively.

\section{B. Adjustment speed by deviation from target leverage and cash flow outcome}

So far the analysis was based on the implicit assumption that all firms adjust to the target with the same speed. From this point on different 
adjustment speeds are allowed across different circumstances. First, the adjustment speed is estimated for over-levered and under-levered firms. Consistent with existing studies (Byoun 2008, Faulkender et al 2012), the results indicate that over-levered firms adjust faster than under-levered firms. Specifically, the adjustment speed is $36 \%(43 \%)$ and $22.2 \%(20.5 \%)$ for over- and under-levered firms, respectively, when book (market) leverage is considered. ${ }^{13}$

The estimation of equation (5) allows for different adjustment speeds across groups of firms with different deviations from target leverage and different cash flow outcomes. The results are presented in table 3. In terms of both book and market leverage, all 4 adjustment speed coefficients are positive and significant, implying that leverage is mean-reverting. Moving on to the comparison of the coefficients between groups, the evidence is not consistent with dynamic trade-off theory. Firms with financial deficits adjust faster when they are over-levered than when they are under-levered. The results are similar under both leverage specifications. The coefficient estimates imply that over-levered firms eliminate on average $38.4 \%$ (37.5\%) of the deviation from target leverage per year in terms of book (market) values while under-levered eliminate just $22.4 \%$ (19\%) per year. The t-test p-values indicate that the differences are highly significant. This implies that firms adjust faster when they issue equity rather than debt, which is a less costly security to issue.

\section{Adjustment speed and adjustment cost determinants}

In the next test, the sample is divided by firm size and by firm risk and the speed of adjustment is estimated for every new group. The number of usable observations in each pair of groups varies according to the availability of the required data. Firm bond ratings are available on Compustat for the years from 1985 onwards. Furthermore, daily stock market data on the CRSP/Compustat merged database is available from 1984 onwards. Paired t-tests are conducted to test the significance of the difference of the coefficients between groups. The results are reported in table 4. Panel A presents results for book leverage and Panel B for market leverage.

Regarding the cases where target adjustment requires equity issuance, there is no evidence found indicating that lower costs imply

\footnotetext{
13. Detailed results are not reported for brevity, but are available upon request.
} 


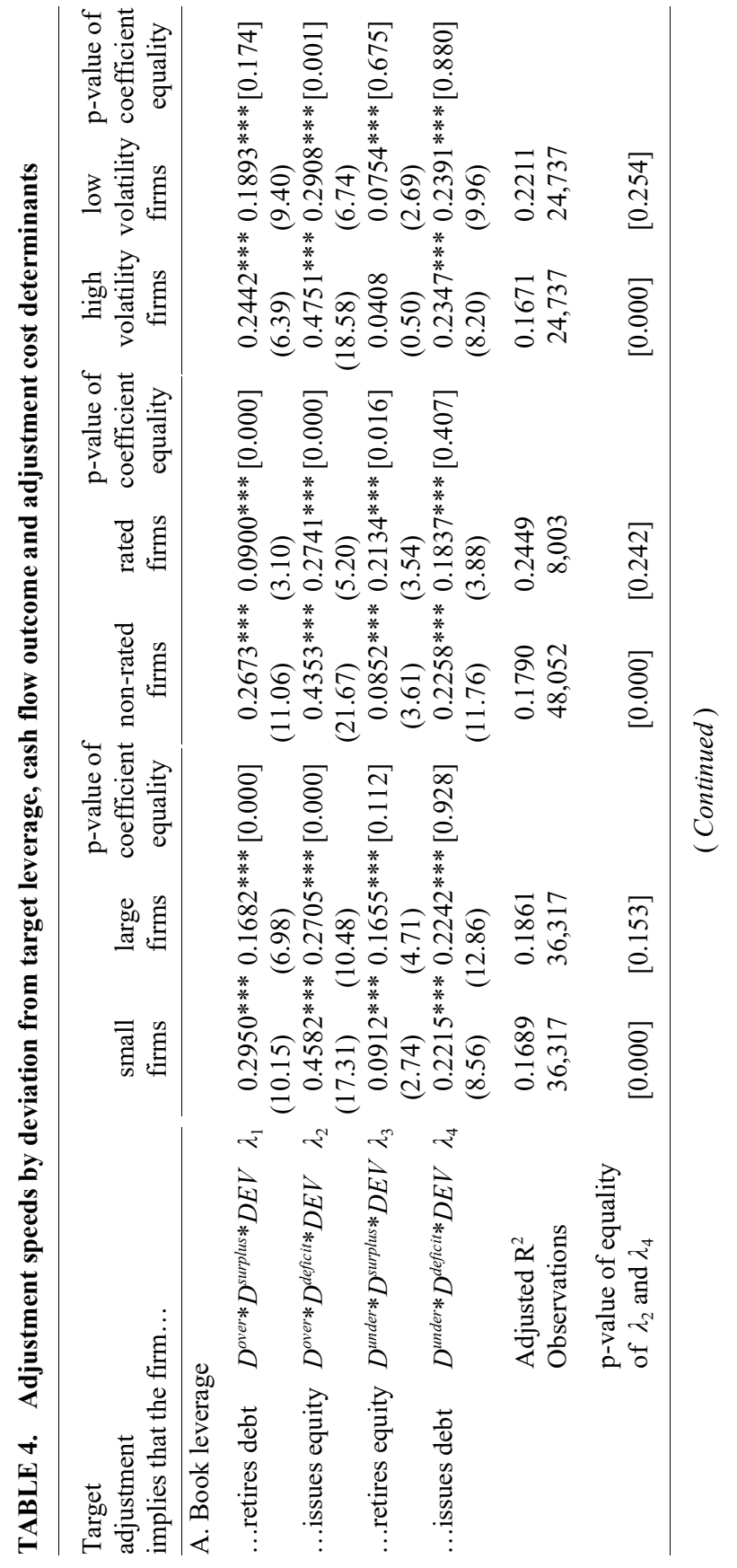




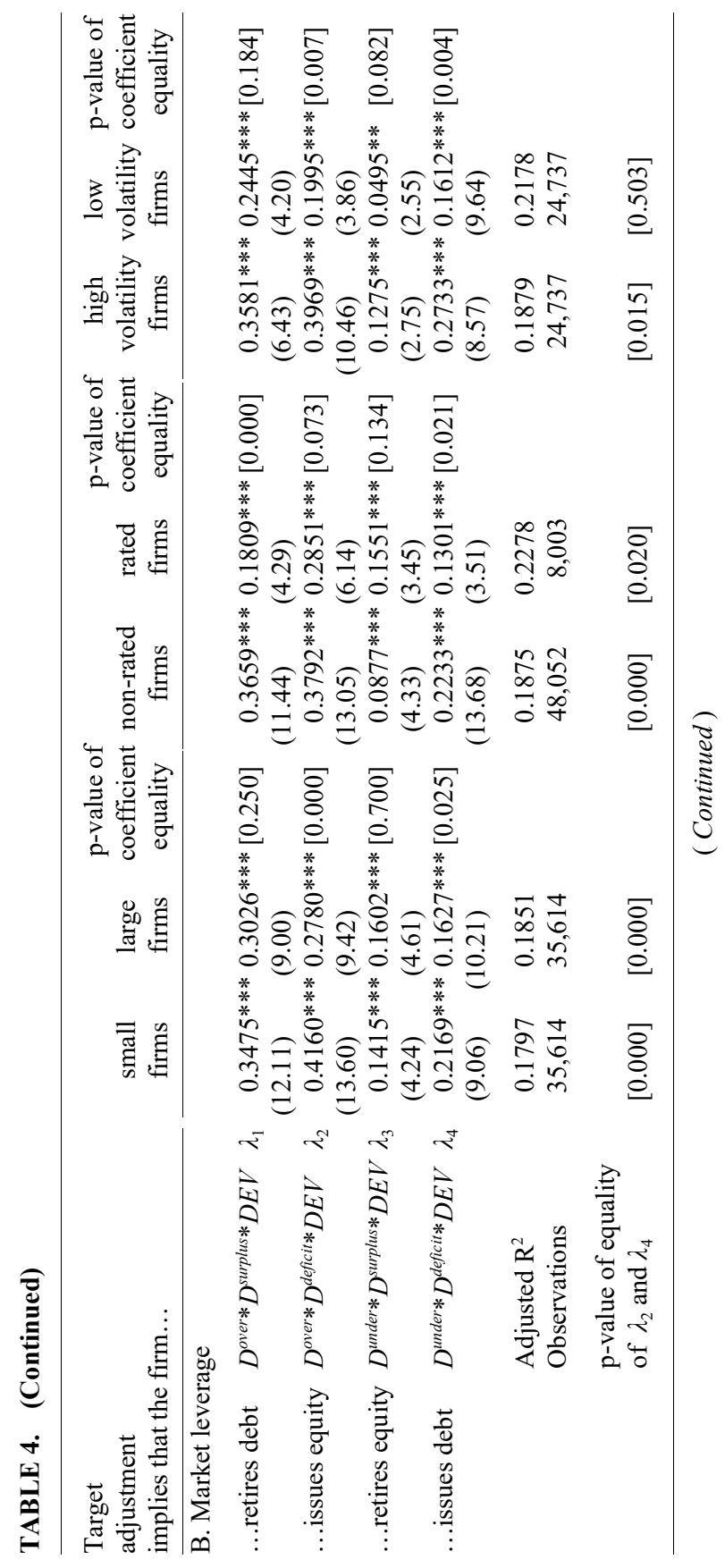




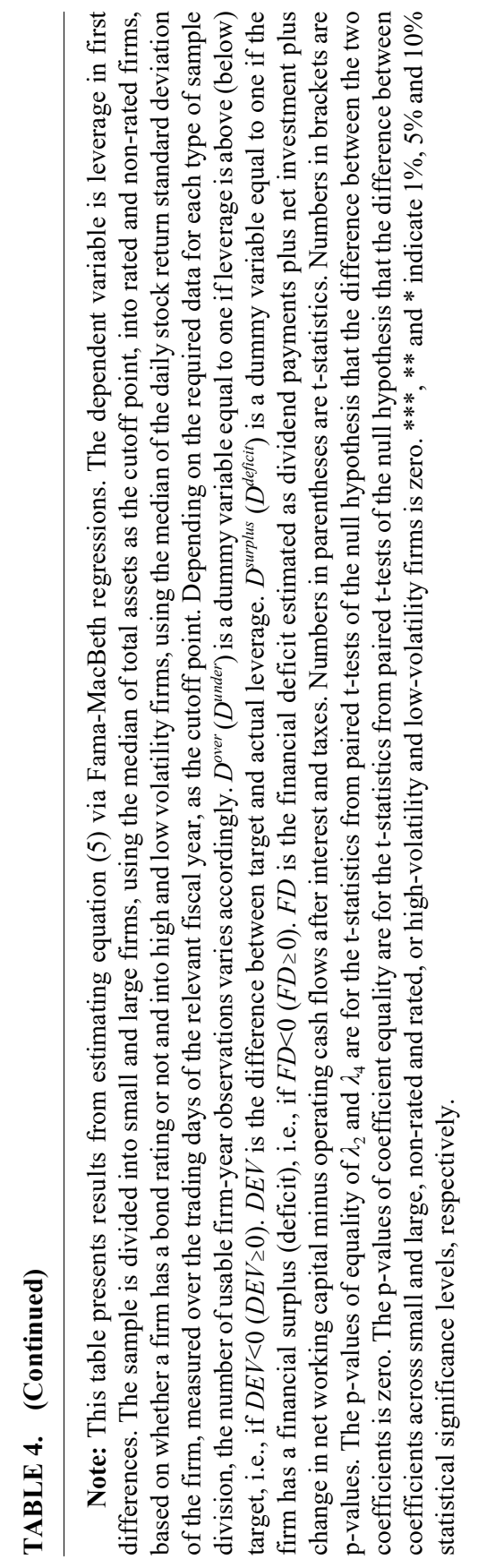


higher speed. According to the estimates for book (market) leverage, the adjustment speed decreases to $27.1 \%(27.8 \%)$ for large firms compared to $45.8 \%(41.6 \%)$ for small firms, to $27.4 \%$ (28.5\%) for rated firms compared to $43.5 \%$ (37.9\%) for non-rated firms and to $29.1 \%$ (19.9\%) for low volatility firms compared to $47.5 \%$ (39.7\%) for high volatility firms. All these differences are statistically significant, most of them at the $1 \%$ level. These estimates indicate that adjustment speed falls as adjustment costs fall, an observation that is contradictory to dynamic trade-off theory.

The results for the cases where target adjustment requires debt issuance point in the same direction. In terms of book leverage, when firms issue debt, the estimates for $\lambda_{4}$ suggest that the adjustment speed is not affected by the variation of adjustment costs. The difference in adjustment speed between large and small, rated and non-rated and high and low volatility firms is statistically not different from zero. When market leverage is considered, adjustment speed estimates are lower for firms that face lower costs. In particular, the speed drops to $16.3 \%$ for large firms from $21.7 \%$ for small firms, to $13 \%$ for rated firms from $22.3 \%$ for non-rated firms and to $16.1 \%$ for low volatility firms from $27.3 \%$ for high volatility firms. All differences are statistically significant at the $5 \%$ level. The results for both leverage specifications are contradictory to dynamic trade-off theory, which predicts that the adjustment speed is negatively associated with adjustment costs.

Splitting the sample into sub-groups offers the opportunity to test the robustness of previous results, concerning the question of whether firms adjust faster when they issue equity or when they issue debt. I compare within each sub-group the adjustment speed between under- and over-levered firms with a financial deficit, by statistically testing the difference between coefficients $\lambda_{2}$ and $\lambda_{4}$. The results are reported in table 4. Across all six sub-groups and both leverage specifications, the speed of adjustment of over-levered firms facing a financial deficit is either higher or not statistically different from the adjustment speed of under-levered firms facing a financial deficit. Put simply, there is no evidence found in favor of the implication of the dynamic trade-off theory, that firms should adjust faster when they issue debt rather than equity.

One might argue that the three adjustment cost proxies might be correlated. For instance, rated firms may be, at the same time, large firms and the ones that have low volatility stocks. Therefore I further split these groups into sub-groups and estimate the model again (e.g., 
small and rated vs. small and non-rated, etc) to control for potential correlation between cost determinants. The results indicate that the positive association between adjustment costs and adjustment speeds (or the lack of any association) remains in the subgroups in most cases. ${ }^{14}$ For example, small non-rated firms adjust faster than large non-rated firms when issuing equity. Likewise, when only large firms are considered, high volatility firms adjust faster than low volatility firms.

The next test explores the incremental effect of the three cost determinants on adjustment speed. The results, reported in table 5, are in line with the findings from previous analysis, indicating that in most cases higher adjustment costs are either positively or not associated with adjustment speed.

Panel A presents the results for the book leverage specification. When issuing equity, the adjustment speed of a firm that is one standard deviation above the mean size is $8.5 \%$ lower than that of an average size firm. Furthermore, firms with a bond rating adjust by $20.3 \%$ slower than unrated firms on average. Likewise, a firm, whose stock return volatility is one standard deviation higher than the average stock return volatility, adjusts by $10.1 \%$ faster than a firm with the average stock return volatility. In a nutshell, when issuing equity, firms that face higher adjustment costs, i.e. small, unrated or high volatility firms, adjust faster. When firms issue debt, the incremental effect of firm size is an exception, in the sense that it is found positive and significant, implying a negative relation between adjustment costs and adjustment speed. Specifically, the adjustment speed of a firm that is one standard deviation above the mean size is $2.2 \%$ higher than that of an average size firm. However, this is a rather weak result in both economic and statistical terms. The incremental effect is estimated at $2.2 \%$, while all other estimated incremental effects range between $8.5 \%$ and $20.3 \%$. Furthermore, in statistical terms, it is only marginally significant at the $10 \%$ level. Regarding the debt rating, the difference in the adjustment speed between rated and unrated firms is statistically insignificant. Finally, the adjustment speed of a firm whose stock return volatility is one standard deviation higher than the average stock return volatility does not statistically differ from that of a firm with an average stock return volatility

Panel B of table 5 presents the results for the market leverage specification. The results are similar to those of the book leverage specification, in the sense that there is no evidence of a negative relation

14. Results are not reported to save space. They are available on request. 


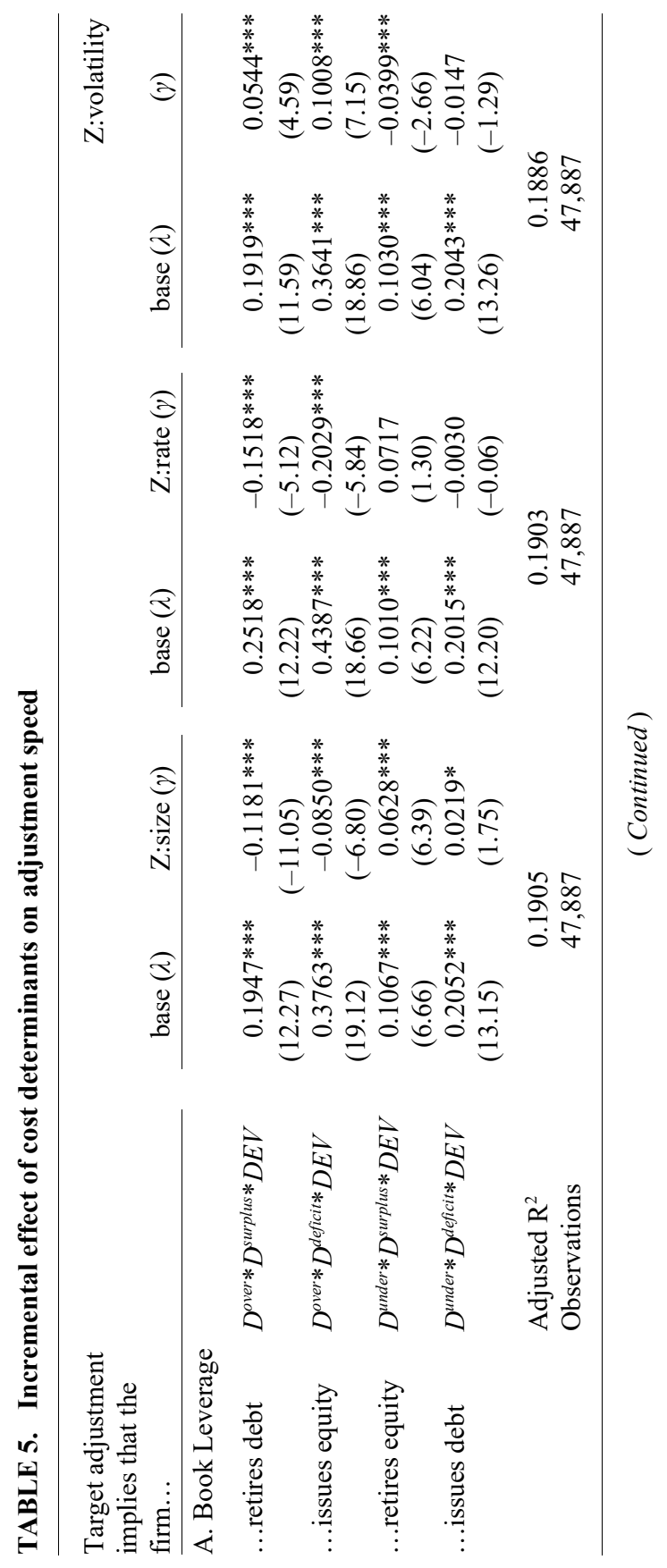




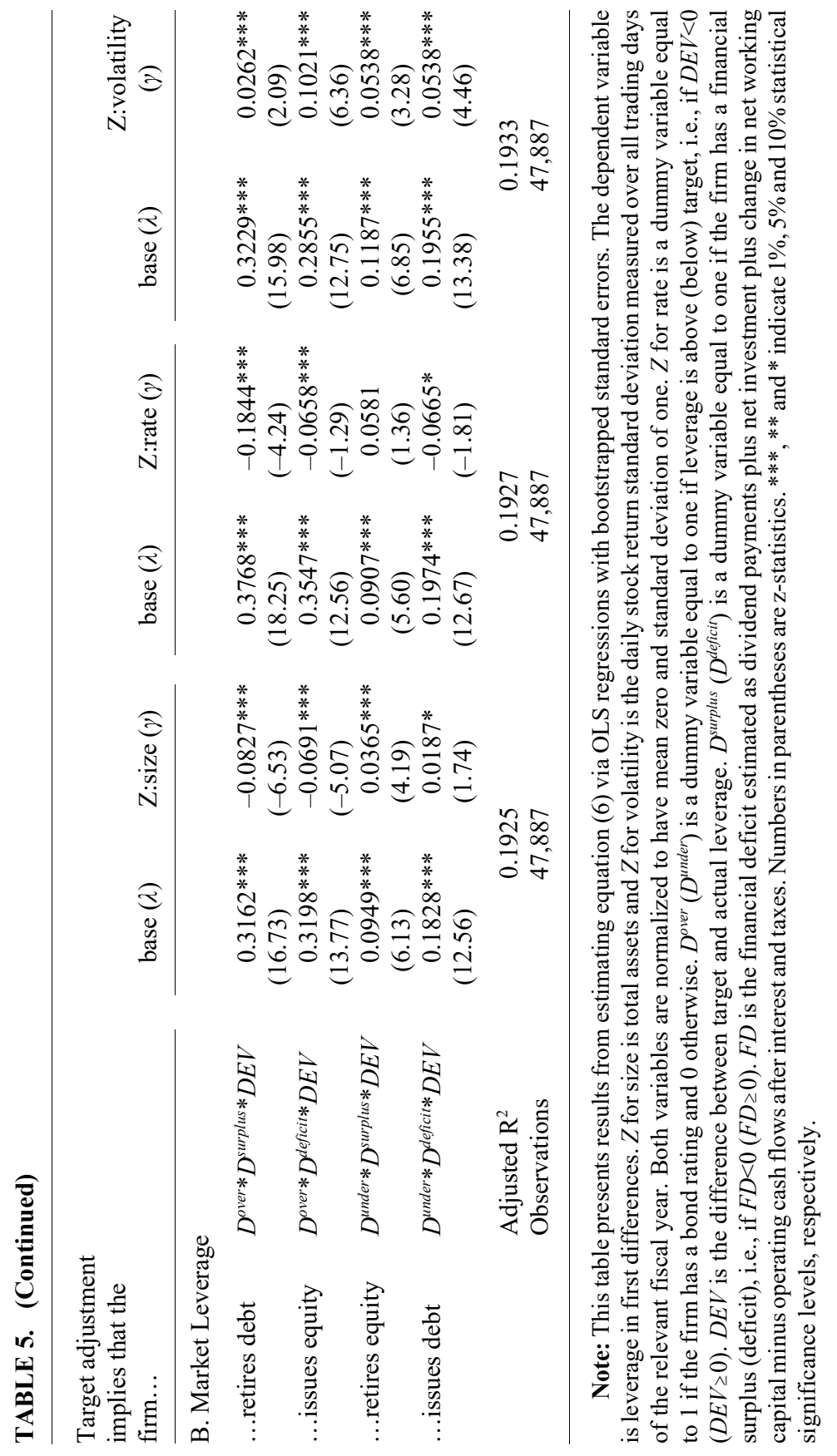


between adjustment costs and adjustment speed.

In the last test debt and equity issuance costs are estimated via the empirical models of Altinkiliç and Hansen (2000) specified by equations (7) and (8). Proceeds are the net increase in debt each fiscal year or the net value of equity issued each fiscal year. As before, in order to qualify as a debt or equity issue, the change must be at least $5 \%$ of the book value of assets in the previous fiscal year. The firm's market capitalization is measured at the end of the relevant fiscal year. In order for the estimated costs to be relevant, it is very important to form a sample that is similar to that of Altinkiliç and Hansen (2000). Therefore, the sample selection criteria suggested by Altinkiliç and Hansen (2000) are applied. Equity or debt issues smaller than $\$ 10$ million or larger than $\$ 1$ billion in terms of proceeds are excluded. ${ }^{15}$ For debt issues, firms without an investment grade bond rating are also excluded. As posted in table 6, the two new confined samples - the one for debt issues and the one for equity issues - are very similar to those of Altinkiliç and Hansen (2000) in terms of estimated issuance costs, proceeds, market capitalization and stock return volatility. For example, the average issuance cost for debt in the sample of Altinkiliç and Hansen is 1.09\% .${ }^{16}$ The average issuance cost for debt in my sample, as estimated by equation (8), is $16.27 \%$. When the sample is constrained on the basis of Altinkiliç and Hansen selection criteria, the average cost drops to $1.19 \%$, closely resembling the average cost in the sample of Altinkiliç and Hansen.

The two samples are split again into two groups, using the medians of the estimated debt and equity issuance costs as the cutoff point. In the debt issues sample, I focus on the adjustment speed of under-levered firms that face a financial deficit, i.e., on firms that have to issue debt, in order to approach their target leverage. Hence, the coefficient of interest is $\lambda_{4}$. Panel A of table 7 reports the results for the book leverage specification. The adjustment speed for high cost firms is $15.1 \%$, while that of low cost firms is $12.1 \%$. Most importantly, the difference between the two estimates is statistically insignificant, as indicated by a Wald test. In the equity issues sample, I focus on the adjustment speed of over-levered firms that face a financial deficit, i.e., on firms that have to issue equity, in order to approach their target leverage. Hence, the

15. In my sample this is translated into $\$ 8$ million and $\$ 875$ million respectively, because Altinkiliç and Hansen measure variables in 1990 dollars

16. The issuance cost is the underwriter spread, which is the compensation paid to the underwriter for selling the firm's security issue, as a percent of the capital raised. 
TABLE 6. Debt and equity issuance cost estimates

\begin{tabular}{|c|c|c|c|c|}
\hline & & $\begin{array}{l}\text { Debt issues: } \\
\text { Altinkiliç } \\
\text { and Hansen } \\
\text { sample }\end{array}$ & $\begin{array}{l}\text { Debt issues: } \\
\text { My sample } \\
\text { (Altinkiliç } \\
\text { and Hansen } \\
\text { selection criteria) }\end{array}$ & $\begin{array}{c}\text { Debt issues: } \\
\text { My sample } \\
\text { (no selection } \\
\text { criteria) }\end{array}$ \\
\hline \multicolumn{5}{|c|}{ A. Debt issuance cost $=0.50+25.17 *(1 /$ proceeds $)+4.63 *($ proceeds $/$ market cap $)$} \\
\hline \multirow[t]{2}{*}{ Proceeds } & mean & 146 & 236 & 75 \\
\hline & median & 119 & 171 & 11 \\
\hline \multirow[t]{2}{*}{ Market cap } & mean & 3,280 & 4,505 & 859 \\
\hline & median & 1,830 & 2,429 & 68 \\
\hline \multirow[t]{2}{*}{ Volatility } & mean & $1.97 \%$ & $2.03 \%$ & $3.68 \%$ \\
\hline & median & $1.80 \%$ & $1.90 \%$ & $3.24 \%$ \\
\hline \multirow[t]{2}{*}{ Issuance cost } & mean & $1.09 \%$ & $1.19 \%$ & $16.27 \%$ \\
\hline & median & & $1.07 \%$ & $4.82 \%$ \\
\hline \multirow[t]{3}{*}{ Observations } & & 628 & 1,770 & 33,372 \\
\hline & & & Equity issues: & \\
\hline & & $\begin{array}{l}\text { Equity issues: } \\
\text { Altinkiliç } \\
\text { and Hansen } \\
\text { sample }\end{array}$ & $\begin{array}{c}\text { My sample } \\
\text { (Altinkiliç } \\
\text { and Hansen } \\
\text { selection criteria) }\end{array}$ & $\begin{array}{c}\text { Equity issues } \\
\text { My sample } \\
\text { (no selection } \\
\text { criteria) }\end{array}$ \\
\hline \multicolumn{5}{|c|}{ B. Equity issuance cost $=4.04+25.65 *(1 /$ proceeds $)+2.64 *($ proceeds $/$ market cap $)$} \\
\hline \multirow[t]{2}{*}{ Proceeds } & mean & 47 & 49 & 24 \\
\hline & median & 33 & 26 & 7 \\
\hline \multirow[t]{2}{*}{ Market cap } & mean & 341 & 733 & 380 \\
\hline & median & 153 & 295 & 85 \\
\hline \multirow[t]{2}{*}{ Volatility } & mean & $3.60 \%$ & $3.89 \%$ & $4.67 \%$ \\
\hline & median & $3.43 \%$ & $3.62 \%$ & $4.32 \%$ \\
\hline \multirow[t]{2}{*}{ Issuance cost } & mean & $5.38 \%$ & $5.62 \%$ & $21.83 \%$ \\
\hline & median & & $5.43 \%$ & $8.32 \%$ \\
\hline Observations & & 1,325 & 8,197 & 17,755 \\
\hline
\end{tabular}

Note: Debt/equity issuance costs are the percentage underwriter spreads. Proceeds are the net increase in debt each fiscal year or the net value of equity issued each fiscal year. In order to qualify as a debt or equity issue the change must be at least $5 \%$ of the book value of assets in the previous fiscal year. Market cap is the market capitalization of the firm at the end of the relevant fiscal year. The estimated cost for each year is assumed to apply for all issuances that took place in that particular year. Volatility is the daily stock return standard deviation of the firm, measured over the trading days of the relevant fiscal year. According to Altinkiliç and Hansen (2000) sample selection criteria, equity or debt issues smaller than $\$ 10$ million or larger than $\$ 1$ billion in proceeds (in my sample this is translated to $\$ 8$ millions and 875 millions respectively, because Altinkiliç and Hansen measure variables in 1990 dollars) are excluded. For debt issues, firms without an investment grade bond rating are also excluded. Variables are trimmed at the 99th percentile. All monetary variables are measured in 1983 (million) dollars using the US CPI as a deflator. 


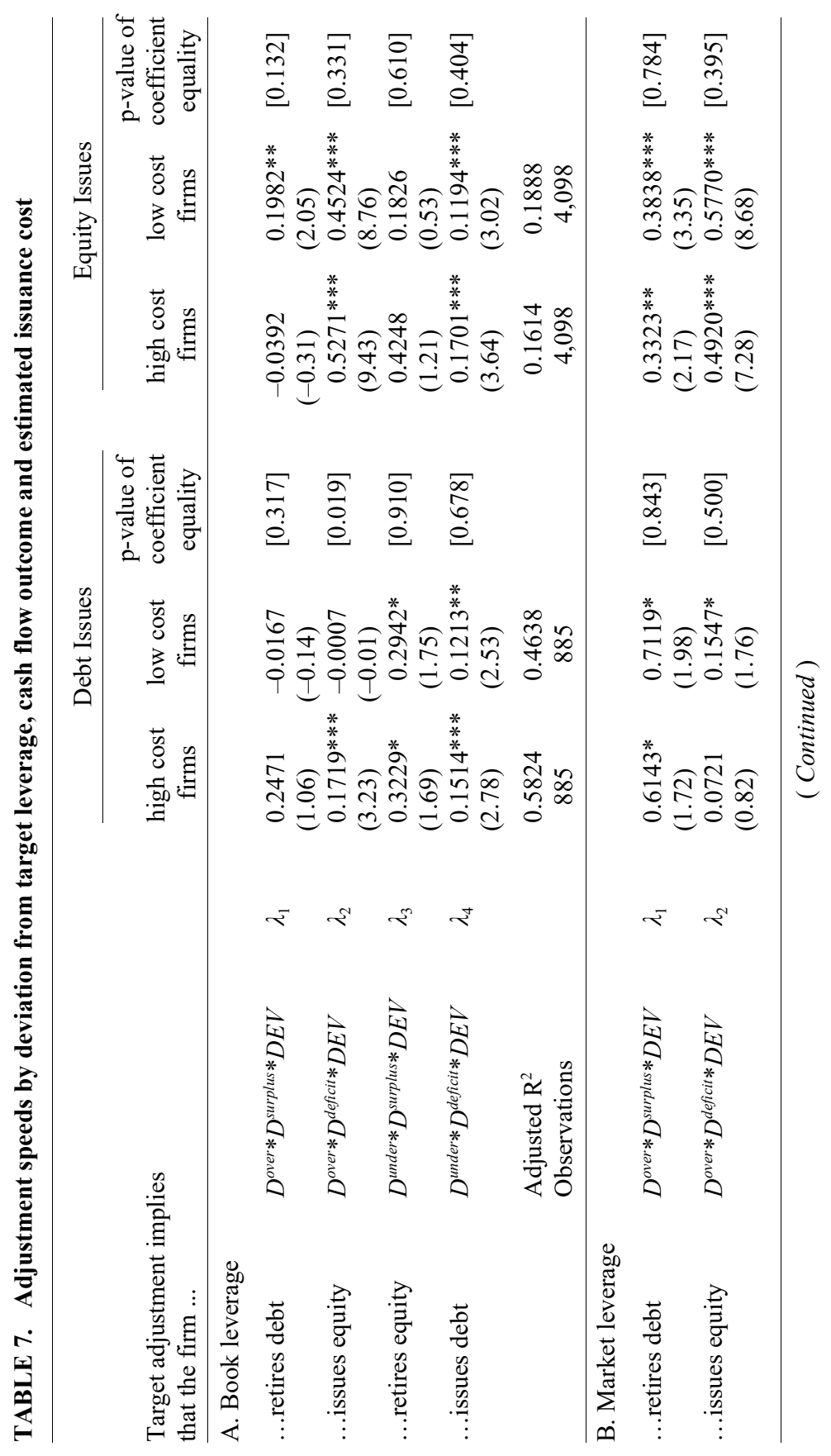




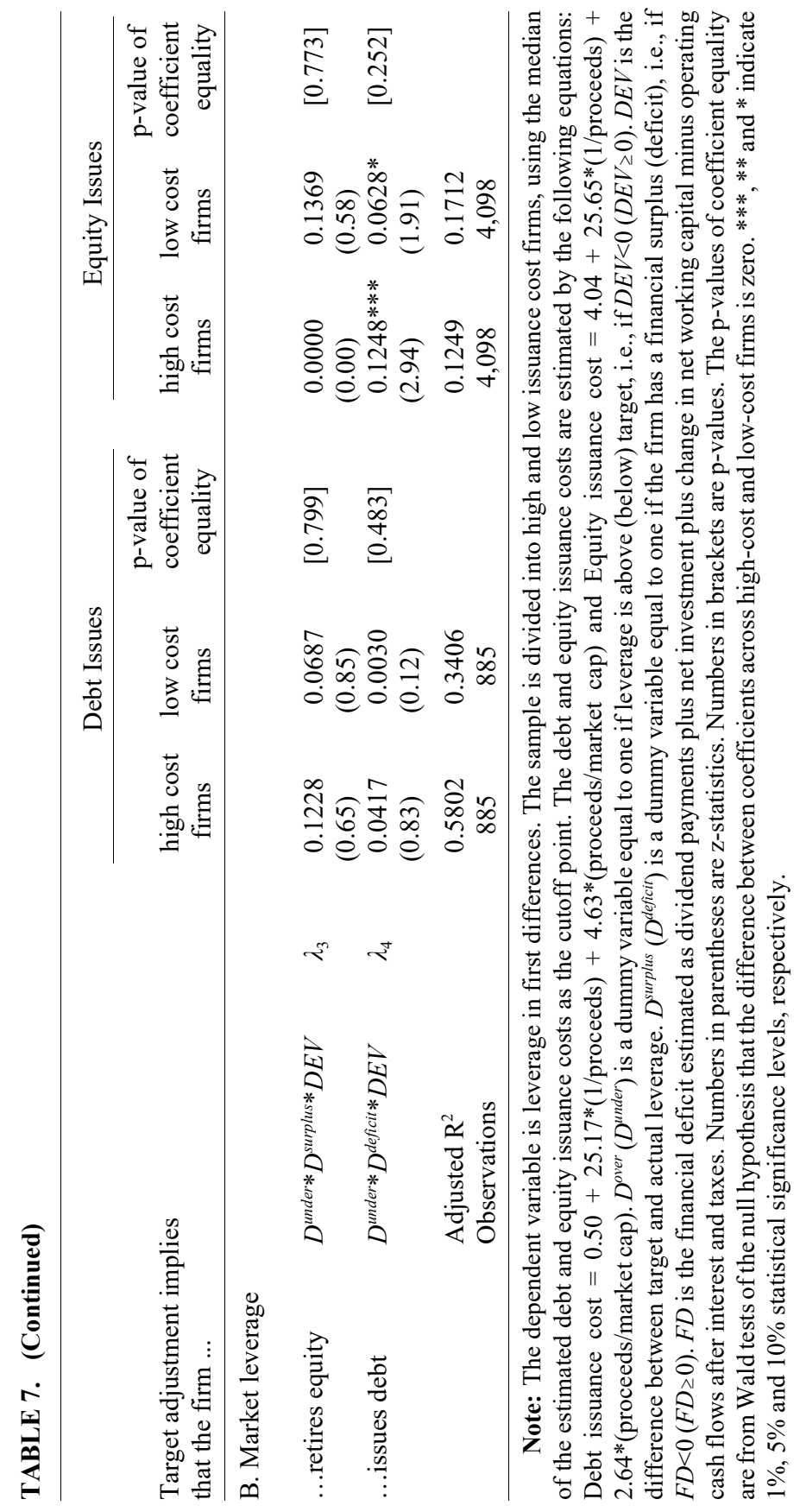


coefficient of interest is $\lambda_{2}$. As reported in Panel A of table 7, high cost firms close $52.7 \%$ of the gap between actual and target leverage per year, while low cost firms $45.2 \%$. However, the difference is statistically insignificant. Panel B of table 7 reports results for market leverage, which are similar to those for book leverage, in the sense that neither when issuing equity nor when issuing debt do low-cost firms adjust faster than high cost firms.

\section{Robustness checks}

The first robustness check is about the mechanical mean reversion of leverage. ${ }^{17}$ Leverage ratios are by definition bounded between zero and one. Therefore, leverage ratios that approach these boundaries are more likely to experience a change towards the mean, than towards the two extreme values. Furthermore, leverage ratios of one or zero cannot go up or down respectively. If they change, they will move towards more moderate levels. Several studies (e.g., Kayhan and Titman, 2007; Chang and Dasgupta, 2009; Hovakimian and Li, 2011) argue that this feature of leverage ratios can lead to mechanical mean reversion and therefore can create an upward bias in the estimated speed of adjustment. Hovakimian and Li (2011) show that mechanical mean reversion generated by this feature prevents the partial adjustment model from rejecting the null hypothesis of zero adjustment speed, in cases that it should. Prior studies suggest that dropping observations with very high or/and very low values (Kayhan and Titman, 2007; Hovakimian and Li, 2011) of leverage ratios mitigates the bias. Following some recent empirical studies (Öztekin and Flannery, 2012; Warr et al., 2012), I drop leverage observations greater than 0.9 and less than 0.1 . I re-run all my tests, using the new truncated sample. The results remain qualitatively unchanged. This implies that the findings of this study are not affected by a potential upward bias in the estimated adjustment speeds, induced by extreme leverage ratio values.

Another concern is that, beyond issuance costs, a firm's speed of adjustment to its target debt ratio may be affected by its position vis-a-vis other target investment and financial decisions. In order to address this concern, I split my sample into financially constrained and unconstrained firms and re-run the tests only for the group of unconstrained firms. The rationale is as follows. Investment and other

17. Detailed results are not presented for brevity throughout Section V, but are available upon request 
financial decisions are expected to affect the speed of adjustment of financially constrained rather than unconstrained firms. As Byoun (2008) correctly points out, financially constrained firms that face negative cash flow shocks may decide to absorb them internally by adjusting their investments, their net working capital or their dividend payments, instead of resorting to prohibitively expensive external capital. In that case, these firms will not respond quickly to deviations from their target leverage and hence the estimated adjustment speed will be low or even insignificant. On the contrary, the speed of unconstrained firms is less likely to be affected by such constraints.

I re-run all tests using a sub-group of my initial sample, that consists of financially unconstrained firms only. The criterion for detecting financially unconstrained firms is similar to the one used by Korajczyk and Levy (2003). A firm is categorized as financially unconstrained if it has investment opportunities and at the same time distributes cash to its debtholders or equityholders. So, for every particular firm-year, a firm is characterized as financially unconstrained if (a) it has paid dividends or has made a debt or equity repurchase during that year and (b) its Tobin's Q, defined as the sum of the market value of equity and the book value of debt divided by the book value of assets, is greater than one. All models are re-estimated for the unconstrained group and no evidence of negative association between adjustment costs and adjustment speed is found. This implies that the other target investment and financial decisions do not drive the results.

Another robustness check concerns the time horizon over which leverage changes take place. When estimating target leverage, following the standard practice of existing studies, I implicitly assume that leverage adjusts within one year to changes in leverage determinants. However, theoretical models do not explicitly show that this horizon has to be one year. Furthermore, there are intuitive arguments suggesting that leverage adjustment over longer horizons cannot be ruled out. In particular, managers may respond slowly to changes in factors that determine leverage, because they might be interested in more permanent leverage determinant changes, i.e., changes that persist more than one year and are not transitory. In addition, potentially high fixed transaction costs may prevent managers from making capital structure adjustments every period. Previous empirical evidence of infrequent leverage adjustments (Leary and Roberts, 2005) is consistent with this view.

An augmented version of equation (2) is needed to capture potential leverage adjustments that extend beyond the one-year period. Therefore, target leverage is re-estimated from equation (2) after additional lags of 
the independent variables are incorporated into the equation. The optimal number of lags is determined by estimating the model with alternative lag lengths (1 through 12 lags) and choosing the one suggested by the Bayesian Information Criterion (BIC). The results suggest that four is the optimal number of lags. This finding implies that changes in leverage determinants can affect target leverage for the next four years.

I re-run all my tests, using the estimated four-year target leverage. The results remain qualitatively unchanged compared to the results from the base specification.

Finally, another concern arises from the length of my sample period. Specifically, the sample period consists of the period in which operating cash flows (OCF) were not required to be disclosed or calculated in a specific way and the period after 1988 during which the FASB statement on the preparation of cash flows was in effect. I re-run all models for each of the two sub-periods and the results remain qualitatively unchanged.

\section{Conclusions}

The focus of this paper is to empirically test one of the central predictions of dynamic trade-off theory of capital structure. In particular, a rather common characteristic across dynamic trade-off models is that security issuance implies transaction costs (e.g., Fischer, Heinkel and Zechner, 1989; Strebulaev, 2007). This translates to the empirical hypothesis that actual debt ratios will revert towards an optimum/target level, as firms will let their leverage ratio move away from their optimal level until the benefits from rebalancing outweigh transaction costs. The goal of this study is to identify cross-sectional variation in adjustment costs (security issuance costs) and test whether such costs are correlated with capital structure choices. If adjustment costs do really impede firms from reaching their desired level of leverage, then higher adjustment costs should be associated with slower movements towards target leverage and vice versa. In contrast to the existing papers, this approach employs directly measurable proxies for adjustment costs, i.e., security issuance cost determinants.

Although evidence in favor of mean-reversion is detected, there is no evidence found that supports the predicted negative relationship between adjustment speed and adjustment costs. In particular, the results suggest that firms make the financial choices that will move them closer to their targets regardless of the security they need to 
issue/repurchase. However, when cases of debt and/or equity issuance are considered, the estimates imply that firms adjust faster when they issue equity rather than debt, a result that contradicts dynamic trade-off, as equity is a more costly security to issue. Furthermore, the results indicate that large firms do not adjust faster than small firms, firms whose debt is rated do not adjust faster than firms without a bond rating and low-volatility firms do not adjust faster than high-volatility firms. All these findings are inconsistent with the predictions of dynamic trade-off theory. Alternative tests concerning (i) the incremental effect of costs on adjustment speed and (ii) the estimated security issuance costs obtained from Altinkiliç and Hansen (2000) models deliver similar results.

In summary, this analysis indicates that the speed of adjustment does not increase as costs decrease. In contrast, the correlation between adjustment cost and the speed of adjustment appears to be either positive or zero. From a dynamic trade-off perspective, these results are puzzling in the sense that firms confronting lower costs should adjust faster.

However, these results do not necessary invalidate the basic idea behind dynamic trade-off models. These findings suggest that either transaction costs are irrelevant to the adjustment process or that the partial adjustment model currently used in the literature is incapable of determining whether firms follow the financial policy suggested by the dynamic-trade-off theory. The latter conjecture seems more plausible, given (i) theoretical predictions and (ii) empirical evidence from survey studies (Graham and Harvey, 2001; Bancel and Mitoo, 2004; Brounen, de Jong and Koedijk, 2006). Regarding the theoretical predictions, some aspects of the theory are ignored in empirical testing. In particular, adjustment costs and expectations about the firm's financing needs in subsequent periods are two factors that are considered by most dynamic trade-off theoretical models to affect corporate financing choices. Empirical models currently used take explicitly into account only the adjustment costs. Regarding the empirical evidence from survey studies, corporate CFOs are primarily concerned about the future investment needs and future cash flow outcomes of their firms when they set their firms' financing policy. Additionally, they consider these expectations to be more important than the maintenance of the firm's debt ratio. Hence, empirical models may be extended to include additional elements that proxy for expectations. I consider this to be a fruitful avenue for future capital structure research.

Accepted by: P.C. Andreou, PhD, Editor-in-Chief(Pro-Tem), October 2015 
Appendix A. Definition of variables used

\begin{tabular}{|c|c|c|}
\hline Symbol & Description & Compustat Accounts \\
\hline & Leverage definitions & \\
\hline$T D / B A$ & $\begin{array}{l}\text { Long-term debt plus debt in current } \\
\text { liabilities to book assets }\end{array}$ & $(\mathrm{DLTT}+\mathrm{DLC}) / \mathrm{AT}$ \\
\hline$T D / M A$ & $\begin{array}{l}\text { Long-term debt plus debt in current } \\
\text { liabilities to market value of assets }\end{array}$ & $(\mathrm{DLTT}+\mathrm{DLC}) / \mathrm{mv} \_\mathrm{a}$ \\
\hline \multirow[t]{2}{*}{$m v \_a$} & $\begin{array}{l}\text { Market value of assets = Book assets } \\
\text { minus total equity plus preferred } \\
\text { stock minus deferred tax and } \\
\text { investment tax credit plus market } \\
\text { equity (market equity }=\text { stock market } \\
\text { price times shares outstanding) }\end{array}$ & $\begin{array}{l}\text { AT-SEQ-TXDITC+PREF_ST+ } \\
\text { (CSHO*PRCC_F) }\end{array}$ \\
\hline & Target leverage variables & \\
\hline Med & $\begin{array}{l}\text { The median leverage ratio of the } \\
\text { industry (based on Fama-French } \\
49 \text { industry groups), that the firm } \\
\text { belongs to. }\end{array}$ & \\
\hline EBITDA & $\begin{array}{l}\text { Earnings before interest, taxes, } \\
\text { depreciation and amortization to } \\
\text { book assets }\end{array}$ & OIBDP/AT \\
\hline$M B$ & $\begin{array}{l}\text { Market value of assets to book } \\
\text { assets }\end{array}$ & mv_a/AT \\
\hline $\operatorname{Ln} A$ & $\begin{array}{l}\text { Natural logarithm of real book } \\
\text { assets expressed in } 1983 \text { US dollars }\end{array}$ & $\log (\mathrm{AT} / \mathrm{CPI})$ \\
\hline$D E P$ & $\begin{array}{l}\text { Depreciation \& amortization to } \\
\text { book assets }\end{array}$ & $\mathrm{DP} / \mathrm{AT}$ \\
\hline$F A$ & Fixed assets to book assets & PPENT/AT \\
\hline$R \& D$ & $\begin{array}{l}\text { Research \& development expense to } \\
\text { net sales }\end{array}$ & XRD/SALE \\
\hline \multirow[t]{2}{*}{$R \& D$ dummy } & $\begin{array}{l}\text { Dummy variable equal to one if the } \\
\text { firm doesn't report R\&D expense } \\
\text { and zero otherwise }\end{array}$ & $\begin{array}{l}\text { dummy: } 1 \text { if XRD missing, } \\
0 \text { otherwise }\end{array}$ \\
\hline & Cash flow variables & \\
\hline$O C F$ & $\begin{array}{l}\text { Operating cash flows after interest } \\
\text { and taxes }\end{array}$ & $\begin{array}{l}\text { Format code 1,2,3: IBC+XIDOC } \\
+ \text { DPC+TXDC+ESUBC+SPPIV } \\
\text { +FOPO+FSRCO } \\
\text { Format code 7: OANCF-RECCH- } \\
\text { INVCH-APALCH-TXACH } \\
\text { +EXRE-AOLOCH }\end{array}$ \\
\hline
\end{tabular}




\begin{tabular}{|c|c|c|}
\hline Symbol & Description & Compustat Accounts \\
\hline$I N V$ & Net investment & $\begin{array}{l}\text { Format code 1,2,3: CAPX } \\
+ \text { IVCH+AQC+FUSEO } \\
\text {-SPPE-SIV } \\
\text { Format code 7: } \\
\text { CAPX+IVCH+AQC-SPPE } \\
\text {-SIV-IVSTCH-IVACO }\end{array}$ \\
\hline$\Delta D$ & Net total debt issues & $\begin{array}{l}\text { Format code } 1: \text { DLTIS } \\
\text {-DLTR-DLCCH } \\
\text { Format code } 2,3,7 \text { : DLTIS } \\
\text {-DLTR+DLCCH }\end{array}$ \\
\hline$\Delta E$ & Net equity issues & $\begin{array}{l}\text { Format code } 1,2,3,7 \text { : } \\
\text { SSTK-PRSTKC }\end{array}$ \\
\hline$\Delta W$ & $\begin{array}{l}\text { Change in net working } \\
\text { capital }\end{array}$ & $\begin{array}{l}\text { Format code 1: WCAPC } \\
\text { +CHECH } \\
\text { Format code 2,3: } \\
\text {-WCAPC+CHECH } \\
\text { Format code 7: - RECCH } \\
\text {-INVCH-APALCH-TXACH } \\
\text {-AOLOCH+CHECH-FIAO }\end{array}$ \\
\hline$D I V$ & Dividend payments & Format code $1,2,3,7: \mathrm{DV}$ \\
\hline
\end{tabular}

\section{References}

Altinkiliç, O., and Hansen, R. 2000. Are there economies of scale in underwriter spreads? Evidence of rising external financing costs. Review of Financial Studies 13: 191-218.

Andrade, G., and Kaplan, S. 1998. How Costly Is Financial (Not Economic) Distress? Evidence from Highly Leveraged Transactions That Became Distressed. Journal of Finance 53: 1443-1493.

Bancel, F., and Mittoo, U. R. 2004. Cross-Country Determinants of Capital Structure Choice: A Survey of European Firms. Financial Management 33: 103-32.

Blundell, R., and Bond, S. 1998. Initial Conditions and Moment Restrictions in Dynamic Panel Data Models. Journal of Econometrics 87: 115-143.

Bradley, M.; Jarrell, G.; and Kim, E. H. 1984. On the Existence of an Optimal Capital Structure: Theory and Evidence. Journal of Finance 39: 857-878.

Brounen, D.; de Jong, A.; and Koedijk, K. 2006. Capital Structure Policies in Europe: Survey Evidence. Journal of Banking \& Finance 30: 1409-42.

Byoun, S. 2008. How and when do firms adjust their capital structure toward targets? Journal of Finance 63: 3069-3096. 
Chang, X., and Dasgupta, S. 2009. Target behavior and financing: How conclusive is the evidence? Journal of Finance 64: 1767-1796.

Eckbo, B. E.; Masulis, R.W.; and Norli, Ø. 2008. Security Offerings. Chapter 6. In B. E. Eckbo (ed.). Handbook of Corporate Finance: Empirical Corporate Finance. Elsevier/North-Holland: Handbooks in Finance Series.

Fama, E., and French, K. 2002. Testing trade-off and pecking order predictions about dividends and debt. Review of Financial Studies 15: 1-33.

Fama, E., and French, K. 2005. Financing decisions: Who Issues Stock? Journal of Financial Economics 76: 549-582.

Fama, E., and MacBeth, J. 1973. Risk, return, and equilibrium: Empirical tests. Journal of Political Economy 81: 607-636.

Faulkender, M.; Flannery, M.; Hankins, K.; and Smith, J. 2012. Cash flows and leverage adjustments. Journal of Financial Economics 103: 632-646.

Fischer, E.; Heinkel, R; and Zechner, J. 1989. Dynamic capital structure choice: theory and tests. Journal of Finance 44: 19-40.

Flannery, M., and Hankins, K.W. 2013. Estimating dynamic panels in corporate finance. Journal of Corporate Finance 19: 1-19.

Flannery, M., and Rangan, K. 2006. Partial adjustment toward target capital structures. Journal of Financial Economics 79: 469-506.

Frank, M., and Goyal, V. 2003. Testing the pecking order theory of capital structure. Journal of Financial Economics 67: 217-248.

Graham, J. 2000. How big are the tax benefits of debt? Journal of Finance 55: 1901-1941.

Graham, J. R., and Harvey, C. R. 2001. The theory and practice of corporate finance: evidence from the field. Journal of Financial Economics 60: 187243.

Hovakimian, A. and Li, G. 2011. In search of conclusive evidence: How to test for adjustment to target capital structure. Journal of Corporate Finance 17: 33-44.

Hovakimian, A. and Li, G. 2012. Is the partial adjustment model a useful tool for capital structure research? Review of Finance 16: 733-754.

Hovakimian, A.; Opler, T.; and Titman, S. 2001. The debt-equity choice.

Journal of Financial and Quantitative Analysis 36: 1-24.

Huang, R., and Ritter, J. 2009. Testing theories of capital structure and estimating the speed of adjustment. Journal of Financial and Quantitative Analysis 44: 237-271.

Ju, N.; Parrino, R.; Poteshman, A.M.; and Weisbach, M.S. 2005, Horses and rabbits? Trade-off theory and optimal capital structure. Journal of Financial and Quantitative Analysis 40: 259-281.

Kayhan, A., and Titman, S. 2007. Firms' histories and their capital structures. Journal of Financial Economics 83: 1-32.

Kim, D.; Palia, D.; and Saunders, A. 2008. The impact of commercial banks on underwriting spreads: Evidence from three decades. Journal of Financial and Quantitative Analysis 43: 975-1000. 
Korajczyk, R., and Levy, A. 2003. Capital structure choice: macroeconomic conditions and financial constraints. Journal of Financial Economics 68: 75-109.

Leary, M., and Roberts, M.R. 2005. Do firms rebalance their capital structures? Journal of Finance 60: 2575-2619.

Lemmon, M.; Roberts, M.; and Zender, J. 2008. Back to the beginning: persistence and the cross-section of corporate capital structure. Journal of Finance 63: 1575-1608.

Myers, S., and Majluf, N. 1984. Corporate financing and investment decisions when firms have information investors do not have. Journal of Financial Economics 13: 187-221.

Modigliani, F., and Miller, M.H. 1958. The cost of capital, corporate finance and the theory of investment. American Economic Review 48: 261-297.

Öztekin, Ö., and Flannery, M. 2012. Institutional determinants of capital structure adjustment speeds. Journal of Financial Economics 103: 88-112.

Strebulaev, I.A. 2007. Do tests of capital structure theory mean what they say? Journal of Finance 62: 1747-1787.

Warr, R.S.; Elliott, W.B.; Koëter-Kant, J.; and Öztekin, Ö. 2012. Equity Mispricing and Leverage Adjustment Costs. Journal of Financial and Quantitative Analysis. 47: 589-616.

Weiss, L.A. 1990. Bankruptcy resolution: direct costs and violation of priority of claims. Journal of Financial Economics 27: 285-314. 